\title{
Zonguldak İli Kentlerinin Kent Dijitalleşme Endekslerine Göre Sıralanması ve Dijitalleşme Seviyelerinin Kent Dijitalleşme Haritaları ile Görselleştirilmesi
}

\author{
Mustafa Çoruh ${ }^{1}$ \\ ORCID: 0000-0002-7114-0372
}

\author{
Halil İbrahim Cebeci² \\ ORCID: 0000-0001-5058-7741
}

Öz

Yeni mobil ve dijital teknolojilerin dijital nesnelerle bütünleşmeye ve kentlerin dijitalleşerek Akıllı Kent ( $A K)$ haline gelmeye başlaması kent hizmetlerinin verimli ve etkin bir şekilde yerine getirilmesinde önemli hale gelmektedir. AK uygulamaları kent güvenliğinin sağlanmasında, adreslerin bulunmasında, trafikte akışkanlık, enerji tasarrufu ve verimlilik sağlanması ve belediye hizmetlerinin etkinleştirilmesinde önemli imkânlar sunmaya başlamıştır. Bu yüzden "Kentlerin Dijitalleşme seviyesinin ölçülmesi kentlerin (yöneticilerinin) en önemli sorunlarından (görevlerinden) birisi olarak belirlenmiş" ve araştırmada bu duruma çözüm aranmıştır. Bu doğrultuda yapılan bu araştırmada Literatür taraması ve mülakatlar vasıtasıyla kentlerin dijitalleşmesini etkileyen boyutlar, Kritik Başarı Faktörleri (KBF) ve göstergeler literatür taraması ve saha araştırmasıyla belirlenmiştir. Bu unsurlar yardımıyla Zonguldak ilindeki sekiz ilçenin dijital dönüşümünü etkiyen gösterge verileri toplanarak ilçelerin "Kent Dijitalleşme Endeksi" (KDE) hesaplanmış ve "Kent Dijitalleşme Haritaları" (KDH) yardımıyla ilçe belediyeleri bazında dijitalleşme seviyeleri görselleştirilmiştir. Her kentin hazırlanan tabloda listelenen göstergelerin toplam değerlerine bağhl olarak dijitallik seviyesinin farklı olduğu görülmüştür. Her bir KBF'nin kent verileriyle ölçülebilmesi için ilgili gösterge değerlerinin kent paydaşları olan belediye, BTK, TSO, Türk Telekom, Emniyet Müdürlüğ̈̈, SGK, MEB, kaymakamlik ve TUIKK'den toplanması ve analiz edilerek KDH ile görselleştirilmesi ve KDE değeri doğrultusunda kentlerin dijital dönüşüme hazırlık veya AK olma seviyesinin ölçülmesi bu araştırmanın önemini artırmaktadır.

Anahtar Kelimeler: Akıllı Kentler, Dijital Dönüşüm, Kent Dijitalleşme Endeksi, Kent Dijitalleşme Haritası, Kritik Başarı Faktörleri.

\footnotetext{
${ }^{1}$ Öğr. Gör., Ataşehir Adıgüzel MYO, E-mail: mcoruh@mustafacoruh.com

${ }^{2}$ Dr. Öğr. Üyesi, Sakarya Üniversitesi E-mail: hcebeci@sakarya.edu.tr

idealkent @ Kent Araştırmaları Dergisi (Journal of Urban Studies)

http://idealkentdergisi.com
}

Geliş Tarihi Received Date: 3.12.2019 Kabul Tarihi Accepted Date: 19.07.2020 


\title{
Ranking the Towns of Zonguldak Province According to the Urban Digitization Indices and Visualizing the Digitization Levels with Urban Digitalization Maps
}

\author{
Mustafa Çoruh ${ }^{3}$ \\ ORCID: 0000-0002-7114-0372
}

*

\author{
Halil İbrahim Cebeci ${ }^{4}$ \\ ORCID: 0000-0001-5058-7741
}

\begin{abstract}
The integration of new mobile and digital technologies into city assets becomes important in the productive and effective implementation of urban services. One of the most important events of today seems to be the digitalization of cities which creates Smart Cities (SC). SC implementations have started to offer important opportunities in ensuring city security, finding addresses, providing fluidity in traffic, invoicing utility services, saving energy in using city resources, and activating municipal services. Therefore, "Measuring the level of digitalization of cities has been identified as one of the most important problems (duties) of cities (managers)" and a solution was sought in the research. The dimensions, Critical Success Factors (CSF) and indicators that affect digitalization of cities have been compiled by means of literature review and field interviews. With the help of an arranged Excel table, the indicator data affecting the digital transformation of eight towns in Zonguldak province were collected and the "Urban Digitalization Index" (UDI) of the towns was calculated and "Urban Digitalization Maps" (UDM) were used to visualize the digitalization status of towns. It is seen that the digitalization level of each town is different depending on the total values of the indicators listed in the prepared table.
\end{abstract}

Keywords: Smart Cities, Digital Transformation, City Digitalization Index, City Digitalization Map, Critical Success Factors.

\footnotetext{
${ }^{3}$ Instructor, Ataşehir Adıgüzel Vocational School, E-mail: mcoruh@mustafacoruh.com

${ }^{4}$ Asts. Prof., Sakarya University, E-mail: hcebeci@sakarya.edu.tr

idealkent @ Kent Araştırmaları Dergisi (Journal of Urban Studies) 


\section{Giriş}

Günümüzde Dijital devrim her alanda iş yapmanın ve yaşamanın kurallarını baştan aşağı değiştirmektedir. Kentlerin yönetimleri de bundan etkilenmektedir. Yeni dijital teknolojilerin yayılması kentlerin yönetim modellerini ve süreçlerini dönüştürmektedir. Bu açıdan kentlerde, ülkeler, firmalar, STK'lar ve üniversiteler gibi Dijital çağa uyum sağlayarak dijital dönüşümlerinin yollarını bulmak zorundadır. Günümüzde İnternet ve Bilişim Teknolojilerinin yükselişinden önce kurulmuş olan tüm özel ve kamu kurumları gibi binlerce yıllık geçmişleri olan kentlerde ciddi zorlukla karşı karşıyadır. Bu açıdan kentlerin sürdürülebilir bir gelişim için dijitalleşmesi kaçınılmaz gözükmektedir. Bir kentin dijitalleşmesinin Akıllı Kent (AK) haline gelmesi anlamına geldiği (Satyam, 2017) unutulmamalıdır.

Araştırma Problemi: Günümüzde Kentlerin birçok sorunla uğraşmak zorunda olduğu aşikârdır. Kaynakların verimsiz ve etkisiz kullanımı, merkezi yönetim vesayeti, kaynakların tükenmesi, sürdürülemez hizmetler, küresel ısınma, kirlilik, hızlı nüfus artışı, teknolojik değişimler, dijital bölünme, çarpık kentleşme, yoksulluk, işsizlik, savaşlar, trafik tıkanıklığı ve göçler bunlardan bazılarıdır. Bu sorunları çözebilmek için uluslararası kuruluşlar, hükümetler (ülkeler), STK'lar, iş dünyası, akademi ve halk arasında daha fazla işbirliği yapılmalıdır. Bu işbirliğinin sağlanması için dijitalleşen verilerin ve enformasyonun paylaşılması gerekmektedir. İnternet, bu paydaşlar arasındaki çabaları koordine etmek için ana iletişim, depolama ve işleme aracı haline gelmiştir. Yeni Bilişim ve İletişim Teknolojilerini (BİT) kullanmadan burada bahsedilen kent sorunlarından sadece bazılarını çözmek bile zordur. Bu yüzden kentlerin sorunlarını çözebilmek için kent yöneticilerinin BİT'leri kullanması ve kentlerinin dijitalleşmesini sağlanmaları en önemli görevlerinden birisi haline gelmiştir.

Sorunların çözülmesi için gerekli verilerin toplanması, analiz edilmesi ve ilgili birimler ve paydaşlar arasında paylaşılması gerekli olduğundan bu işlemi yerine getiren BİT araçlarının öneminin giderek artacağı söylenebilir. Bu araçlar arasındaki bağlantıyı da İnternetin kablolu ve kablosuz teknolojiler (Wi-Fi, 4/5G) vasıtasıyla yerine getirdiği görülmektedir. Bu yüzden kentlerde kablosuz internet yatırımlarının hizlanarak devam etmesi ve İnternetin kent yöneticileri tarafından bir altyapı hizmeti olarak görülmesinde fayda vardır. Toplanan verilerin Büyük Veri (BV) araçlarıyla analiz edildikten sonra kentle 
ilgili zamanlı ve doğru kararların alınması için İş Zekâsı (IZ) raporlama yazılımlarıyla ilgili karar verici bölümlere dağıtımının yapılması da sağlanmalıdir.

Dünya'da rekabetin ülkeler arasından kentler arasına kaydığı günümüzde (Borja ve Castells, 1997) kent kaynaklarının verimli ve etkin şekilde kullanılarak kente rekabet avantajı sağlanması kentlerin dijitalleşmesini ve dijital teknolojilerin halk, yerel firmalar ve yerel kamu kurumları tarafindan kullanılmasın zorunlu hale getirmektedir. Bu yüzden Kentlerin dijitalleşme seviyesini ölçecek Kritik Başarı Faktörlerinin (KBF) belirlenerek belirli göstergeler eşliğinde hesaplanmasıyla Kentlerin Dijitalleşme Seviyesi veya Dijital Dönüşüme Hazırlık Seviyesi öncelikle belirlenmelidir. Bu amaçla Kent Dijitalleşme Endeks (KDE) değerleri çıkarılmalıdır. Kent yöneticilerinin sonuçları kolayca görebilmesi içinde ölçülen KBF değerlerinin Kent Dijitalleşme Haritası (KDH) şeklinde grafikleştirilmesiyle kolay kavrama ve görselleştirme sağlanacaktır. Kent yöneticileri Dünya'da yaşanan teknolojik ve sosyal değişimleri önleyemeyeceğine göre kentlerinin bu değişimin neresinde olduğunu KDH ve DKE yardımıyla görmeleri gerekmektedir. Bu yüzden "Kentlerin Dijitalleşme seviyesinin ölçülmesi kentlerin (yöneticilerinin) en önemli sorunlarından (görevlerinden) birisi olarak belirlenmiş̧" ve araştırmada bu duruma çözüm aranmıştır.

Araştırmanın Amacı: Kentlerin Dijitalleşmesini etkileyen KBF'lerin belirlenmesi ve bu faktörleri oluşturan göstergelerin belirlenerek değerlendirilmesi sayesinde kentlerin dijitalleşme seviyesi veya AK olmaya hazırlık seviyelerinin belirlenmesi sağlanabilir. Bu araştırmanın amacı "Kentlerin dijitalleşmesini etkileyen Kritik Başarl Faktörlerinin (KBF) belirlenip analiz edildikten sonra Zonguldak ilindeki kentlerin (ilçelerin) Dijitalleşme Endeks (KDE) değerlerine çıkarmak ve bu değere bağh olarak Zonguldak ilindeki kentlerin dijitalleşme seviyelerinin belirlenmesidir."

Araştırma Soruları: Bu araştırmada yukarıda belirtilen amacı gerçekleştirmek doğrultusunda şu sorulara cevaplar aranmıştır:

1. Kentlerin dijitalleşmesini sağlayan boyutlar, KBF'ler ve bunları tanımlayan göstergeler nelerdir?

2. KBF değerleri nasıl ölçülür ve kentler için bir dijitalleşme endeks değeri nasil bulunur?

3. Kentler Dijitalleşme Endeksi (KDE) ile nasıl sıralanabilir?

4. KBF değerleri nasıl görselleştirilebilir? 
5. KDE ve Kent Dijitalleşme Haritalarının (KDH) kent yönetimlerine ve paydaşlarına ne tür faydaları vardır?

Araştırmanın Önemi: Kentlerde kaynakların etkin ve verimli bir şekilde kullanılması için kentte yaratılan, kullanılan ve analiz edilen tüm veri ve enformasyonun dijitalleşmesi gerekmektedir. Burada kentlerin dijitalleşmesini ve dönüşümünü sağlayan boyutların, Kritik Başarı Faktörlerinin belirlenmesi ve göstergelerin incelenmesi bu araştırmanın önemini ortaya koymaktadır. Ayrıca bu araştırma sonunda Kent Dijitalleşme Endekslerinin çıkarılarak kentlerin sıralanması yanında Akıllı Kent (AK) oluşumu bağlamında dijital dönüşümü yöneticilere gösteren "Kent Dijitalleşme Haritalarının" sağlanması araştırmanın önemini artırmaktadır.

Nüfus artışı ve kentleşmenin devam edeceği ve kaynakların azalacağı düşünüldüğünde hâlihazırda var olan kent kaynaklarının etkin ve verimli bir şekilde kullanılmasının öncelikle gerekli olduğu görülmektedir. Bunun içinde dijitalleşen verilere ve enformasyona ihtiyaç vardır. Dijitalleşmeyen veri ve enformasyonun istenen hizda toplanması, depolanması, analiz edilmesi ve karar vericilere dağıtılması veya halka duyurulması imkânsızdır. Bu dijitalleşme sayesinde kentlere rekabet avantajı sağlayan işgücü verimliliğini artırma, firma yenilikçiliğini sağlama ve halk girişimciliğinin desteklenmesi sağlanabilir. Bu yüzden Kentlerin geldiği “Dijitalleşme veya Dijital Dönüşüm seviyesinin ölçülmesi" bu araştırmanın önemini ortaya koymaktadır.

Araştırmanın Hedef Kitlesi: Kent ve Belediye yöneticileri, STK'lar, halk, yerel firmalar, altyapı hizmeti sunan firmalar, AK uygulaması sunan firmalar, yerel ve merkezi kamu kurumları bu araştırmadan fayda sağlayabilirler.

\section{Literatür Taraması}

Akıllı Kent girişimleri sayesinde, kablosuz internet ağıyla oluşturulan Kablosuz Belediye İnternet Ağı (KBİA) şehirler için su, elektrik veya doğalgaz araçlarını okuma, trafik ışıklarını kontrol etme, kent güvenlik sistemlerini kurma, hava durumu için vatandaşları uyarma, belediye hizmetlerini yönetme (itfaiye, çöp toplama vb.), vatandaşlar arasında dijital uçurumu önleme ve Nesnelerin İnterneti (NI) uygulamalarını yaygınlaştırmak için kullanılmaya başlandığı görülmektedir (Coruh, 2009; TT, 2018).

Ayrıca Kent ve Belediye yöneticilerinin kentlerinin dijitalleşmesini sağlamak için Mobil ve sabit İnternet Altyapı stratejilerini kent vizyonu, misyonu 
ve stratejik planlarıyla bütünleştirmelidir. Kentlerdeki tüm evlere bir elektrik bağlantısı, su bağlantısı, telefon bağlantısı, kanalizasyon bağlantısı, yol bağlantısı ve gaz bağlantısı yanında internet bağlantısı da sağlanmalıdır. İnternet kullanımını toplumun tüm kesimlerine yaymak için, kent yöneticilerinin uygun maliyetli ve kolay kullanılabilir bir teknoloji bulması gerekmektedir. $\mathrm{Bu}$ teknoloji Kablosuz Belediye İnternet Ağı (KBİA) olabilir (Çoruh, 2016). Ancak hızla gelişmekte olan $5 \mathrm{G}$ ve Wi-Fi 6.0 teknolojilerinin kent yöneticileri ve diğer kent paydaşlarının en önemli yardımcıları olacakları görülmektedir.

Bu bağlamda günümüzde internet erişimi, Dünya' daki şehirler için bir altyapı hizmeti haline gelmiştir. Şehir yönetimlerinin su veya elektrik sağlama, kanalizasyon hizmeti sunma, çöp toplama veya yolların asfaltlanması gibi birçok kent hizmetinin sunulması ve yönetiminde Kent Bilişim Sistemlerini (KBS) kullanması gerekmektedir. KBS'nin de internete e-Belediye vasitasıyla bağlanarak, her vatandaşın belediyedeki kayıtlarına şifre ile erişmesine izin vermesi desteklenmelidir.

Dijital dönüşümler ile oluşturulmaya başlanan Akıllı Kentlerde (AK) yeni teknolojilerle kent kaynaklarının yararsız kullanımı azaltılarak kent kaynaklarının etkin ve verimli kullanımının artırılacağı öngörülmektedir (Banger, 2017, s. 12). Amaç KBS’ler, Nesnelerin İnterneti, Büyük Veri, İş Zekâsı, Yapay Zekâ, Wi-Fi, 5G ve Bulut Bilişim gibi yeni dijital BİT/Endüstri 4.0 teknolojileri kullanılarak kent kaynaklarının kullanım verimliliğini ve etkinliğini artırmaktır. Bu sayede küresel rekabete, sürdürülebilir bir kent gelişimine, yaratıcı ve yenilikçi firma ve kişiler yanında yatırımcıları da cezbetmeye çalışılmaktadır.

Bu nedenlerle kentlerin dijitalleşmesinin ve bu dijitalleşmenin hangi safhasında olduklarının belirlenmesi yöneticiler ve kent sakinleri için önemli hale gelmektedir. Dünyada dijitalleşmenin gerçekleştiği fiziksel mekânlarda kentlerden başka bir yer değildir. Bu dijitalleşmeye bağlı olarak son yıllarda Akıllı Kentler ortaya çıkmaya başlamıştır.

Öte yandan, (Satyam, 2017) Akıllı Kentin (AK) evrensel bir tanımı olmadığını söyledikten sonra çoğu şehir yönetimlerinin uzun vadeli bir AK vizyonundan ve planlamasından yoksun olduğunu söylemektedir. Bunun temel nedenini de şehirlerin seçilmiş insanlar tarafından yönetilmesine bağlamaktadır. Seçimle gelen başkanların kısa dönemde sonuç alınacak işlere odaklandığını belirtmektedir.

Kısaca, "AK'ler verilerin ve enformasyonun dijital ortamda aktı̆̆g, fiziksel ve sanal varliklarm dijital bir ortamda iletişimde olduğu kentler" olarak tanımlanabilir. Bu yüzden kentlerin Dijital dönüşümünün ve bu dönüşüme bağlı olarak 
Kent Dijitalleşme Endekslerinin çıkarılması önemli bir konu haline gelmektedir. Kentlerin AK olma veya dijitalleşme seviyesine bağh olarak birbiriyle karşılaştırılmalarnı sağlamak ve sıralamak için Dünya'da birçok endeks geliştirilmiş ve geliştirilmeye devam edilmektedir (Nick ve Pongrácz, 2016):

- WSP Küresel Kentler Endeksi,

- TU Wien Avrupa Akıllı Şehirler Sıralaması,

- Boyd Cohen Akıllı Şehir Endeksi,

- IBM Akıllı Şehir Değerlendirmesi,

- Avrupa Dijital Şehir Endeksi (EDCi),

- Akıllı Kent Wien Projesi,

- Satyam Akıllı Kentleri Etkileyen Faktörler,

- İtalya Akıllı Şehir Endeksi,

- Sustaina 100 Kent Endeksi.

- Cisco Global Dijital Hazırlık endeksi,

- Roland Berger Akıllı Kent Strateji Endeksi.

Türkiye'de ise 2016-2019 yıllarında Türkiye Bilişim Vakfı, Vodafone-Deloitte, Çevre ve Şehircilik Bakanlı̆̆ ve İstanbul Büyük Şehir Belediyesi tarafindan yapılmış endeks çalışmaları vardır:

- İstanbul Akıllı Şehir Endeksi (IBB),

- Vodafone-Deloitte "Akıllı Şehirler Yol Haritası",

- Çevre ve Şehircilik Bakanlığı Akıllı Kent Olgunluk Değerlendirme Modeli,

- Türkiye Bilişim Vakfı Türkiye Akıllı Şehirler Değerlendirme Raporu.

$\mathrm{Bu}$ endekslerin oluşturulması içinde birçok boyut, Kritik Başarı Faktörü (KBF) ve göstergeler tanımlanmıştır. Ancak Literatür Taramasında görülen çalışmaların birçoğunda geçen KBF'lerin genellikle teknoloji ağırlıklı olduğu görülmektedir.

Literatürde ve siyasal ortamda AK kavramının çok popüler olmasına ve kullanılmasına rağmen Dünya'da AK uygulamalarının fazla olduğu görülmemektedir. Roland Berger tarafindan 2019 yılında hazırlanan "The Smart City Breakaway " adlı rapora göre Dünya' da küçük büyük 153 kent resmi olarak bir Akıllı Kent stratejisi yayınlamıştır. Bunların 15'inin kapsamlı bir stratejik yaklaşım gösteren planları vardır ve bu 15 'den sadece 8'i ciddi bir uygulamaya sahiptir (Berger, 2019). Türkiye'de ise 5 kent belediyesinde (Denizli, Konya, Kayseri, Bursa, Kütahya) resmi olarak bir AK projesi olduğu ve AK uygulamalarının yapıldığı internet araştırmasından görülmüştür. Bunların 
yanında AK projesi olduğunu belirten 25 adet kent belediyesi daha vardır (Çoruh, 2021).

Türkiye'de kentlerin dijitalleşmesi alanında yapılan en önemli çalışma Çevre ve Şehircilik Bakanlığ1 tarafından hazırlanan "2020-2023 Ulusal Akıllı Şehirler Stratejisi ve Eylem Planıdır." Kentlerin Dijital Dönüşümünü etkileyen 17 adet KBF'nin tanımlandığı bu plan bakanlık bünyesinde kurulan "Akıllı Şehirler ve Coğrafi Teknolojiler Dairesi Başkanlığı" vasıtasıyla hazırlanmıştır. Bu başkanlığın kurulması ile AK'ler konusu Türkiye'de kurumsal bir yapıya dönüştürülmüştür. AK'ler Strateji Eylem Planı Akıllı Kentler konusunda ulusal ortak stratejik bakışı oluşturmak ve bir yol haritası çıarmak için hazırlanmıştır. Bu plan ile insan odaklı "Hayata Değer Katan Yaşanabilir ve Sürdürülebilir Şehirler" vizyon olarak belirlenmiştir (CBSMüdürlüğü, 2019). Coğrafi Bilgi Sistemleri (CBS) Müdürlüğü tarafından hazırlanan bu planın detaylarının anlatıldığı "Akıll Şehirler Beyaz Bülteninde", Kentlerin ihtiyaçlarına çözüm arayışı içinde bulunan kişi ve kurumların, AK çözümleri üreterek kente hizmet edebilmek için öncelikle kentin ne kadar "Akıllı" olduğunu gösterecek bazı değerlendirme araçlarına ihtiyaç duydukları ve bunun için nicel ve nitel araştırma araçlarına ihtiyaç olduğu belirtilmektedir. Zonguldak ilinde yapılan bu araştırmada nicel bir araştırmadır. Diğer yandan son yıllarda yayınlanan eDevlet, Bilgi Toplumu, Dijital dönüşüm ofisi, e-imza gibi birçok eylem planında dijital dönüşümle ilgili birçok atıf olduğunu hatırlatmakta fayda vardir.

Türkiye'de AK'ler konusunda yapılan çalışmaların ayrı bir araştırma konusu olduğu söylenebilir. Bu konuda yapılmış çalışmalar ve yayınlanan makale ve tezlerle ilgili daha detaylı bir listeye https://www.akillisehirler.gov.tr/dokumanlar/ linkinden ulaşlabilir.

Kaynakların incelenmesi doğrultusunda Tablo-1'deki Kentlerin Dijitalleşme boyutları ve Kritik Başarı Faktörleri ve bunların ölçülmesini sağlayacak göstergeler (sadece sayıları verilmiştir) belirlenmiştir. Araştırmada kullanılan 88 adet göstergenin 61 adeti literatür taramasından gelmiş ve 27 adeti ise kent paydaşlarn (TSO yöneticileri, Belediye Bilgi İşlem müdürleri, Türk Telekom Müdürü vs.) ile yapılan saha mülakatlarında teklif edilmiştir. 
Tablo 1. Kentlerin Dijitalleşmesini Etkileyen Boyutlar, KBF'ler ve Göstergeler

\begin{tabular}{|c|c|c|c|c|}
\hline Boyutlar & Boyut Kaynakları & KBF'ler & KBF Kaynakları & $\begin{array}{l}\text { Gösterge } \\
\text { Sayısı }\end{array}$ \\
\hline \multirow{2}{*}{$\begin{array}{l}\text { Akıllı } \\
\text { Teknoloji }\end{array}$} & \multirow{2}{*}{$\begin{array}{l}\text { (Ahvenniemi, Huovila, } \\
\text { Pinto-Seppä, } \\
\text { ve Airaksinen, 2017; } \\
\text { Cisco, 2018; } \\
\text { Kamrysi, Gotzamani, } \\
\text { Andronikidis, ve }\end{array}$} & Teknoloji Altyapısı & $\begin{array}{l}\text { (Cohen, 2015; Ahvenniemi, } \\
\text { Huovila, Pinto-Seppä, \& } \\
\text { Airaksinen, 2017; Cisco, } \\
\text { 2018; EDCi, 2016) }\end{array}$ & 13 \\
\hline & & Teknoloji Kabulü & (Cisco, 2018) & 9 \\
\hline \multirow[t]{2}{*}{$\begin{array}{l}\text { Akıllı } \\
\text { İnsan }\end{array}$} & \multirow{2}{*}{$\begin{array}{l}\text { (Cohen, 2015; IBM, } \\
\text { 2016; SCRanking, 2007; } \\
\text { Kamrysi, Gotzamani, } \\
\text { Andronikidis, } \\
\text { ve Georgiou, 2014) }\end{array}$} & İnsan Sermayesi & $\begin{array}{l}\text { (Ahvenniemi, Huovila, } \\
\text { Pinto-Seppä, \& Airaksinen, } \\
\text { 2017; Satyam, 2017; Cisco, } \\
\text { 2018; EDCi, 2016) }\end{array}$ & 10 \\
\hline & & $\begin{array}{l}\text { İnsan İhtiyaçlarının } \\
\text { Karşılanması }\end{array}$ & (Cisco, 2018; Satyam, 2017) & 10 \\
\hline \multirow[t]{2}{*}{$\begin{array}{l}\text { Akıllı } \\
\text { Yönetişim }\end{array}$} & \multirow{2}{*}{$\begin{array}{l}\text { (Cohen, 2015; IBM, } \\
\text { 2016; SCRanking, 2007; } \\
\text { Ahvenniemi, Huovila, } \\
\text { Pinto-Seppä, } \\
\text { ve Airaksinen, 2017; } \\
\text { Satyam, 2017) }\end{array}$} & Belediye Yönetişimi & $\begin{array}{l}\text { (Cohen, 2015; SCRanking, } \\
\text { 2007; Ahvenniemi, Huovila, } \\
\text { Pinto-Seppä, \& Airaksinen, } \\
\text { 2017) }\end{array}$ & 11 \\
\hline & & $\begin{array}{l}\text { Akıllı Kent } \\
\text { Uygulamaları }\end{array}$ & $\begin{array}{l}\text { (Berger, 2019; Satyam, 2017; } \\
\text { TT, 2018) }\end{array}$ & 11 \\
\hline \multirow{3}{*}{$\begin{array}{l}\text { Akıllı } \\
\text { Ekonomi }\end{array}$} & \multirow{3}{*}{$\begin{array}{l}\text { (Cohen, 2015; IBM, } \\
\text { 2016; SCRanking, 2007) }\end{array}$} & İş Yapma Kolaylığ & (Cisco, 2018; EDCi, 2016) & 8 \\
\hline & & Yenilik Ortamı & (Cisco, 2018) & 9 \\
\hline & & Dijital Pazar & (EDCi, 2016) & 7 \\
\hline
\end{tabular}

\section{Yöntem}

Bu araştırmada kentlerin Dijital Dönüşümüne (DD) katkı sağlayacak boyutlar, Kritik Başarı Faktörleri ve göstergeler ortaya çıarılmaya ve bunların ölçüm yolları belirlenmeye ve şehirleri hesaplanan KDE değerlerine göre sıralayacak ortak bir hesaplama yöntemi geliştirilmeye çalışılmıştır. Bu araştırmada Şehirlerin dijitalleşmesini veya dijital dönüşümünü sağlayacak çözümlerin neler olduğunu keşfetmenin araştırma temel amaçlarından birisi olmadığı unutulmamalıdır.

Araştırma stratejisi olarak öncelikle literatür taraması yardımıyla Kentlerin Dijital Dönüşümünü etkileyen boyutların, Kritik Başarı Faktörlerinin $(\mathrm{KBF})$ ve göstergelerinin belirlenmesine ve toplanacak verilerin Excel tablosu yardımıyla hesaplanmasına karar verilmiştir. Bu hesaplamada Türkiye ortalamalarının standart veri olarak kullanılmasına karar verilmiştir. Bu amaçla Türkiye ortalama verileri ilgili kurumların resmi internet (ikincil kaynak) sitelerinden tedarik edilmiştir. BTK, YÖK, TUIK, TOBB, MEB, TUSİAD, TIMM, TUBİSAT, Türk Patent gibi kurumların istatistik verilerine internetten ulaşıl- 
mıştır. Ancak yıllık ve aylık bazda yayınlanan bu ikincil kaynak verilerin genel olarak Türkiye ve il bazında yayınlandığı görülmüştür. Bu verilerin ilçe bazında toplanabilmesi için ilgili ilçelerdeki kurumların ziyaret edilmesi gerektiği ortaya çımıştır. Bu amaçla İlçe bazındaki verilerin ise mülakat yoluyla ilçelerden toplanmasına karar verilmiştir.

Bu araştırmada Satyam (2017)'nin hesaplama yöntemi kullanılarak kentlerin Dijitalleşme Endeksi ve haritaları çıkarılmıştır. Bu hesaplamada öncelikle her bir KBF'nin hesaplanması için her bir göstergenin değeri ilgili KBF'nin Toplam gösterge değerine bölünerek bir oran bulunmuştur. Bu oran değerlerinin oluşturduğu dokuzgen alanın hesaplanmasıyla da Kent Dijitalleşme Endeks (KDE) değeri hesaplanmıştır.

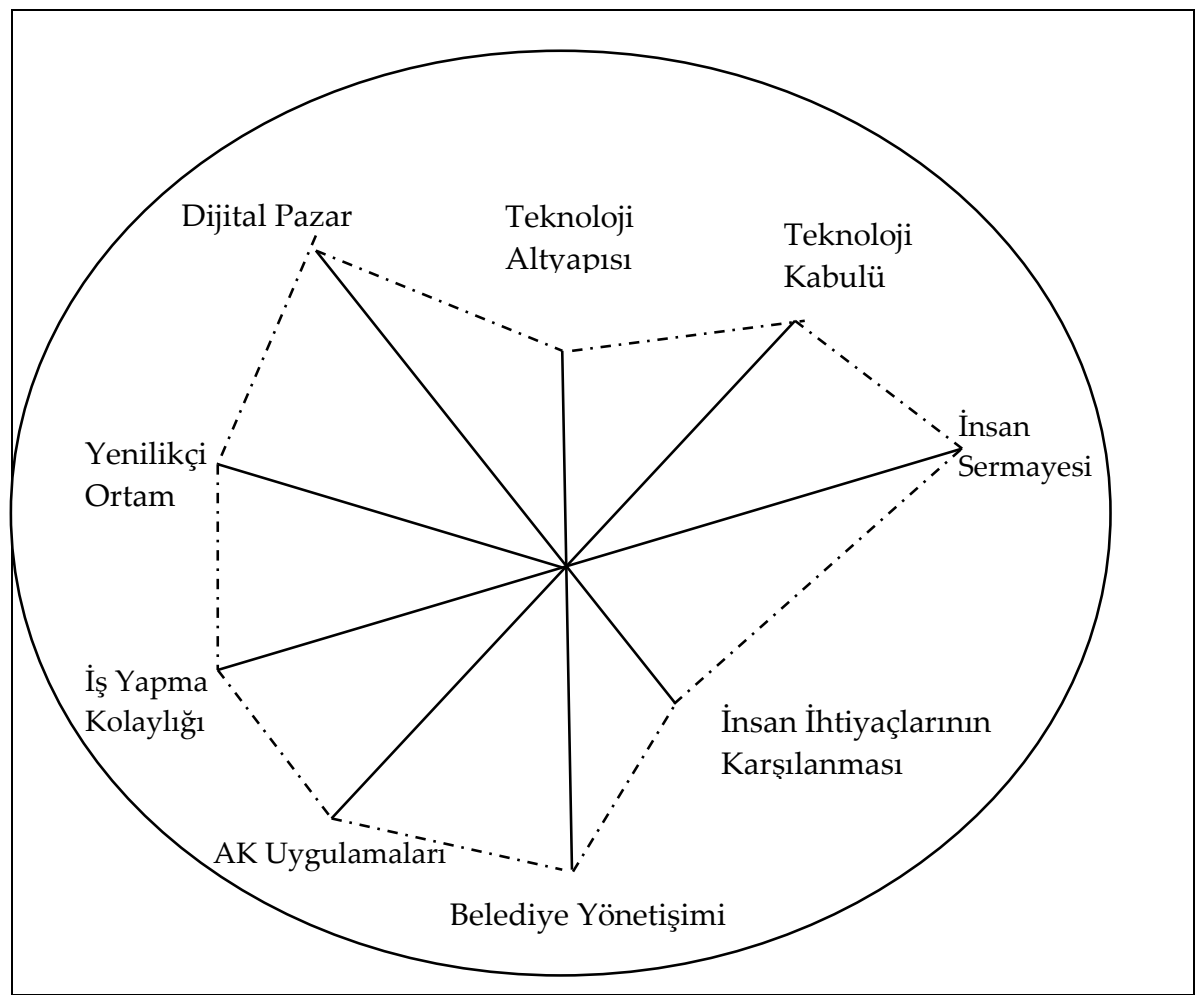

Şekil 1. Akıllı Kent Dijitalleşme Haritası (Satyam, 2017, s. 176)

Bu hesaplamada Tablo-1'de listelenen KBF'ler, dijital şehir yaşamının kalitesine katkıda bulundukları şekilde sınıflandırılmaya çalışılmıştır. Araştırma yapılan her şehir tabloda listelenen $\mathrm{KBF}^{\prime}$ lerin gösterge değerlerine sahip olduğu ve bu gösterge değerlerinin, kapsamları ile bir şehrin Akıllılığını 
veya dijitalleşme seviyesini diğerlerinden ayırdığı farz edilmiştir (Satyam, 2017, s. 175). Hesaplamada kullanılan ' 0 ' değeri, bir göstergenin şehirdeki dijitalleşmeye bir katkısının olmadığını göstermektedir. Toplanan verilerin analiz edildikten sonra Şekil-1' deki gibi bir grafikle (KDH) gösterilmesi, araştırmacının veya yöneticinin bir şehrin tüm Dijitalleşme/Akıllı faktörlerini birlikte görmesini sağlamaktadır. Şekil-1'deki her bir faktör çizgilerinin dış uçları birleştirilerek bir dokuzgen oluşturulmuştur. Bu dokuzgen şehrin akıllı "Kent Dijitalleşme Haritası" olarak kabul edilmektedir (Satyam, 2017, s. 176).

Haritadaki dokuzgenin alan değerinin, şehrin genel Akıllılığını veya Dijitalliğini ölçebileceği ve bu alan değeri daha yüksek olan şehrin daha Dijital bir şehir olduğu kabul edilmektedir. Bu dokuzgen alan, dairenin alanına bölünürse çıan değer, kent dijitalliğini gösteren en iyi oran olarak kabul edilebilir. Bu orana Kent Dijitalleşme Endeksi (KDE) denmektedir. Bu Dijital Endeks Değeri aşağıdaki formülle hesaplanmıştır (Satyam, 2017, s. 177):

- Dijital Endeks = [(Akıllı Alan) $/($ Daire Alanı) $]$

Hesaplanan KDE'ler ile tüm şehirler sıralanabilir ve şehir yöneticileri şehirlerinin dijitalleşmesini değerlendirebilir ve bu değere bağlı olarak iyileştirme olasılıklarını keşfedebilir (Satyam, 2017, s. 177).

Satyam (2017)'nin hesaplama yöntemi doğrultusunda Excel'de hazırlanan Göstergeler tablosu değerlerinin kent bazında nasıl toplanacağını belirlemek için Kdz. Ereğli'de ön araştırma yapılmıştır. Şahsi ilişkiler yardımıyla Türk Telekom, TSO, ilçe Milli Eğitim Müdürlüğü ve Belediye ziyaret edilerek hazırlanan tablo yardımıyla ilçe bazında veriler toplanmış ve bu ziyaretler sırasında hangi tür verilerin nereden toplanabileceği öğrenilmeye çalışılmıştır. Örneğin güvenlik kamerası verilerinin Emniyet müdürlügünden, ilçede çalışan sayılarının İlçe SGK müdürlüklerinden alınması gerektiği ortaya çıkmıştir.

Zonguldak ilinin Sekiz (8) ilçesinde yapılan ilk tur mülakatlar sonunda her ilçeden toplanan veriler Excel tablosunda Satyam (2017)'den alınan AK Endeks formülleri ve AK değerlendirme haritası yardımıyla hesaplanarak ilçelerin bir ön Dijital endeksleri ve Dijitalleşme Haritaları çıkarılmıştır. Toplanan bu ön veriler yardımıyla Araştırmanın KBF'lerini, göstergelerini, Dijitalleşme endeks sıralaması ve Dijitalleşme haritalarını gösteren bir web sitesi tasarlanmış ve Kdz. Ereğli ilçesinin ilk verileri bu sitede ilçe ismi belirtilmeden örnek olarak yayınlanmıştır.

İkinci tur ziyaretler bir hafta sonra yani Ekim ayının son haftası yapılmıştır. Bu ziyaret sırasında her ilçenin derlenen verileri ilgili kişilerle paylaşılmış 
ve web sitesi tanıtılarak gösterilmiştir. Endeks sonuçlarının gösterilmesi ve özellikle Kent Dijitalleşme Haritalarının gösterilerek yorumlanması mülakata katılan kişilerin dikkatini çekmiş ve ilgilerinin artması sağlanmıştır. $\mathrm{Bu}$ sayede özellikle Devrek, Çaycuma ve Zonguldak Bilgi İşlem müdürlerinin kendi uygulamalarıyla ilgili detaylı bilgi paylaştı̆̆ı ve öneriler sunduğu görülmüştür.

İkinci tur görüşme sonunda toplanan veriler ve öneriler doğrultusunda bazı göstergelerin hesaplama yöntemi değiştirilmiştir. Örneğin coğrafi işaret ve Ar-Ge yapan şirket sayısı yerine bunların var mı/yok mu şeklinde toplanmasına ve e-Ticaret verilerinin Zonguldak ili ortalamasına göre hesaplanmasına karar verilerek gerekli düzenlemeler yapılmıştır.

Üçüncü tur görüşmeler Kasım ayının ilk haftası yapılmış ve son haline getirilen Göstergelerin verileri toplanmıştır. Bu turda İnternette hazırlanan bir Anket formu mülakat yapılan kişilere detaylı olarak açıklanarak doldurtulmuştur. Bu anket yardımıyla mülakata katılan kişilerin demografik özellikleri elde edilmiştir. Toplanan son veriler Excel tablosunda ve hazırlanan yazılım vasıtasıyla son hesaplamaları yapılmış ve endeks değerleri vasıtasıyla ilçelerin Dijitalleşme sıralamaları belirlenmiştir. KDE ve KDH verileri ilçe bazında hazırlanmış ve sonuçlar yorumlanarak ilçelerdeki ilgili kişilere Email yoluyla (sadece kendi kentlerine ait sonuçlar) gönderilmiştir.

Yukarıda açıklanan araştırma stratejileri ve yapılan uygulamalardan görüleceği gibi bu araştırmada Araştırma yaklaşımı (metodolojisi) açısından karma bir yaklaşım (pozitivist + yorumlayıcl) kullanılmıştır, çünkü araştırmadaki amaç fenomenleri öngörmek, ölçmek ve tahmin etmekten çok bunları açıklamaktır. Araştırma analizinde ilgili faktörlerin ve göstergelerin açılanması için halk, uzman ve yönetici görüşlerine başvurulduğundan dolayı öncelikle yorumlayıcı bir yaklaşım gerekmiştir. Ayrıca kentlerin dijital dönüşüm seviyelerini ölçen KDE hesaplandığı bir tablo ve formüller kullanılmıştır. Bu tablodaki ilgili göstergelerin her bir değeri ikincil veya birincil kaynaklardan temin edilerek kentlerin dijital dönüşüm seviyeleri ortaya çıkarılmıştır. Bu yüzden pozitivist bir yaklaşım da söz konusudur.

Diğer yandan bir araştırmanın yöntemi, araştırma problemine ve hedeflerine bağlıdır (Zikmund, 2000). Bu araştırmada, kentlerin Dijital Dönüşüm unsurları ve özellikle KBF'leri açıklanacağı ve KBF'ler yardımıyla Kentlerin dijitalleşme seviyeleri veya dijitalleşme endeksleri (KDE) keşfedilmeye çalışılacağı için hem açıklayıcı hem de keșfedici araştırma yöntemleri kullanılmıştır. Keşfedici araştırmalar Ne oluyor? Sorusuna cevap aramak için yapılmaktadır (Coşkun, Altunışık, ve Yıldırım, 2017, s. 75). Bu amaçla yukarıda stratejisi ve 
uygulanma adımları anlatılan araştırmada öncelikle kapsamlı bir literatür taraması yapılmış ve kent paydaşlarıyla mülakat/anket yapılarak KDE değerlerini hesaplayabilecek boyutlar, KBF'ler ve göstergeler keșfedilmiștir. Daha sonra internetten elde edilen ikincil veriler ve mülakat ile anketlerden elde edilen birincil tür verilerle kentlerin dijital dönüşümün neresinde olduğu ve KDE değerleri keşfedilmeye çalışılmıştır. Bu değerlerin keşfedilmesinde Excel tabloları hesaplama ve analiz için kullanılmıştır.

Açılayıcı araştırmalar ise bağımlı ve bağımsız değişkenler arasındaki neden-sonuç ilişkilerini açıklamaya çalışmaktadır. Bu araştırmada bağımsız değişkenler olan dijital dönüşüm $\mathrm{KBF}^{\prime} l e r i$ ve bu $\mathrm{KBF}^{\prime}$ ler vasitasıyla kentlerin KDE ile nasıl sıralanacağı veya sıralama derecesi (bağımlı değişken) nedenleri ve sonuçları açıklanmaya çalışılmıştır. Bu amaçla KDE ve KDH sonuçları analiz edilerek sıralama sonuçları ve bu sonuçların nedenleri açılanmaya ve farklı açılardan anlaşılmaya çalışılmıştır. Örneğin Zonguldak ilindeki araştırmada neden Zonguldak merkez ilçenin en dijital kent ve ilin en küçük ilçesinin 3. sırada olduğu açıklanmıştır.

Veri toplamada öncelikle internetten ikincil kaynak verileri standartların belirlenmesi için kullanılmıştır. İlçelerin verileri ise birincil kaynaklardan mülakat ve anket yöntemleri ile toplanmıştır. Genel hatlarıyla stratejisi, amacı, yöntemleri ve yaklaşımı yukarıda özetlenen araştırmada kullanılan yöntemler Tablo-2'de listelenmiştir.

Tablo 2. Araştırma da Kullanılan Yöntemler

\begin{tabular}{ll}
\hline Araştırmanın Amacı & Kentlerin Dijitalleşme seviyesinin ölçülmesi. \\
\hline Araştırma Stratejisi & $\begin{array}{l}\text { Literatür taraması, mülakat yapılması, anket düzenlenmesi, KDE } \\
\text { ve KDH'ların Excel ile hesaplanması. }\end{array}$ \\
\hline Araştırma Yaklaşımı & Karma (Pozitivist + Yorumlayııı) \\
\hline Araştırma Yöntemi & Açıklayıcı (neden-sonuç ilişkisi) ve Keşfedici (ne oluyor?) \\
\hline Veri Edinme Yöntemi & Mülakat ve istatistik (ikincil) veriler, Anket (Email, internet) \\
\hline Araştırma Süresi & Anlık (Fotoğraf çekimi) 30 Kasım 2019 tarihli veriler. \\
\hline & Dijitalleşme Kritik Başarı Faktörleri (9 Adet) \\
\hline Bağımsı Değişkenler & Dijitalleşme Göstergeleri (88 Adet) \\
\hline Aracı Değişkenler & Kent Dijitalleşme Endeksi ve Kent Dijitalleşme Haritası \\
\hline Bağımlı Değişkenler & Nİ, BB, BV, İZ, e-Belediye, CBS, Belediye BS, KBİA, KGS ve Diğer \\
\hline Kontrol Değişkenleri & Bilişim Sistemleri \\
\hline Gürülttü Değişkenleri & Diş Faktörler (Ekonomi, Siyaset, Teknoloji, Rekabet) \\
\hline & \\
\hline Analiz Yöntemi & Nicel (Kantitatif) ve Nitel (Kalitatif) \\
\hline Analiz Birimi & Kentler \\
\hline Etkilenen Kişiler & Vatandaşlar, STK'lar, Yerel Firmalar, Yerel Kent ve Devlet kurum- \\
\hline lar, Yatırımcılar, Belediyeler
\end{tabular}


Kentlerin dijital dönüşümüne etki eden ekonomik, teknolojik, sosyal, demografik, yerel yönetişim ve yasal göstergelerin araştırmada birlikte kullanılması daha gerçekçi bir endeks değeri bulunmasına yardım etmiştir.

\section{Bulgular}

Araştırma Zonguldak ilinin 8 ilçe belediyesi üzerinde yapılmış ve araştırma eşit ağırlıklı gösterge veri değerleri üzerinden tamamlanmıştır. Araştırmada Türkiye ortalamalarının hesaplanmasında TUIK, BTK, YÖK, TIM, MEB, Patent Kurumu, CI, Invest Turkey, TUBİSAD, TOBB, ATGM, SGK ve EPDK gibi kurumların yayınladığı istatiksel veriler kullanılmıştır. Saha mülakatları sırasında her şehrin dijital dönüşüm boyutları ve KBF değerlerinin hesaplanması için 95 adet gösterge verileri ilgili kurumlardan toplanmıştır. Ancak analiz sırasında bu göstergelerden 7 adetinin aynı değerleri hesapladı̆̆ı görüldüğünden göstergeler 88'e düşürülmüştür. Araştırmada kullanılan hesaplamaların açıklanması için Zonguldak merkez ilçe verileri kullanılabilir. Bu amaçla Zonguldak Merkez ilçesinin genel KDE değeri Tablo-1'de listelenen KBF'leri tanımlayan gösterge değerlerinin analizleri sonunda oluşan oran sonuçları ve hesaplama verileri Tablo-3' de listelenmiş ve Şekil-2' de KDH olarak görselleştirilmiştir.

Tablo 3. Zonguldak Merkez İçe Dijital Dönüşüm Kritik Başarı Faktör (KBF) Değerleri

\begin{tabular}{lllll}
\hline Boyutlar & KBF'ler & Ölçülen (a) & Gereken (b) & Oran (a/b) \\
\hline \multirow{2}{*}{ Akıllı Teknoloji } & Teknoloji Altyapısı & 11,74 & 13 & 0,90 \\
\cline { 2 - 5 } & Teknoloji Kabulü & 7,00 & 9 & 0,78 \\
\hline \multirow{2}{*}{ Akıllı İnsan } & İnsan Sermayesi & 13,67 & 10 & 1,37 \\
\cline { 2 - 5 } & İnsan İhtiyaçlarının Karşılanması & 4,02 & 10 & 0,40 \\
\hline \multirow{2}{*}{ Akıllı Yönetişim } & Belediye Yönetişimi & 5,34 & 10 & 0,53 \\
\cline { 2 - 5 } & Akıllı Kent Uygulamaları & 1,00 & 11 & 0,09 \\
\hline \multirow{3}{*}{ Akıllı Ekonomi } & İş Yapma Kolaylı̆̆1 & 4,71 & 8 & 0,59 \\
\cline { 2 - 5 } & Yenilik Ortamı & 7,21 & 10 & 0,72 \\
\cline { 2 - 5 } & Dijital Pazar & $\mathbf{4 , 6 7}$ & 7 & $\mathbf{0 , 6 7}$ \\
\hline & Toplam & $\mathbf{5 9 , 3 5}$ & $\mathbf{8 8}$ & $\mathbf{0 , 6 7 4}$ \\
\cline { 2 - 5 } & Ortalama & $\mathbf{6 , 5 9}$ & $\mathbf{1 0}$ & $\mathbf{0 , 6 7 2}$ \\
\hline
\end{tabular}

Hesaplamada her bir KBF'nin “Ölçülen” değerleri (a), “Gereken” gösterge sayıları (b) ve Ölçülen/Gereken formülüyle hesaplanan "Oran" değeri (a/b) Tablo-3'de görülmektedir. Buradaki “Ölçülen” gösterge değerleri Türkiye ortalamalarıyla yapılan karşılaştırma değerleri üzerinden hesaplanmıştır. Ör- 
neğin "Sabit telefon abone sayısı" göstergesi BTK istatistiklerinden Türkiye'de bin kişiye 139 adet olduğu hesaplanmıştır. Bu ortalama Zonguldak Merkez ilçesinin nüfusuna göre hesaplandığında 17,366 adet olması gerekmektedir. Kentten gelen veri âdeti ise 22,561 bu iki sayı oranlandığında (17,366/22,561) 1.30 değeri bulunmaktadır. “Teknoloji Altyapısı” faktörünün değerini bulmak için 13 adet gösterge bu şekilde hesaplandıktan sonra oran değerleri toplanmakta $(11,74)$ ve bu değer 13 adet gösterge sayısına bölününce Tablo-3'de görülen “Teknoloji Altyapısı” faktörünün "0,90” değeri bulunmaktadır. Bu işlem her bir gösterge ve KBF için tekrarlanmaktadır. Kısacası $9 \times 88=792$ adet işlem yapılmıştır.

\section{Zonguldak Merkez Kent Dijitalleşme Haritası (KDH)}

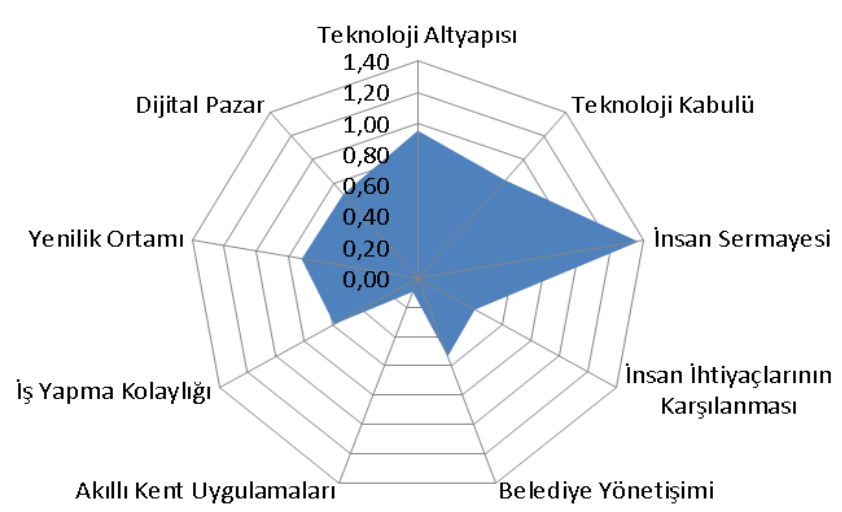

Şekil-2: Zonguldak Merkez İlçe Kent Dijitalleşme Haritası

Tablo-3'deki oranların tek bir Kent Dijitalleşme Endeks değerine dönüştürmek ve Şekil-2'de Zonguldak Merkez ilçe Kent Dijitalleşme Haritasında görülen faktörlerin toplam alan değerinin (üçgenlerin toplam alanları) hesaplanması Tablo-4'deki formüllerle yapılmıştır.

Tablo 4. Zonguldak Merkez İlçe Kent Dijitalleşme Endeks Hesaplama Formülleri (Satyam, 2017, s. 176)

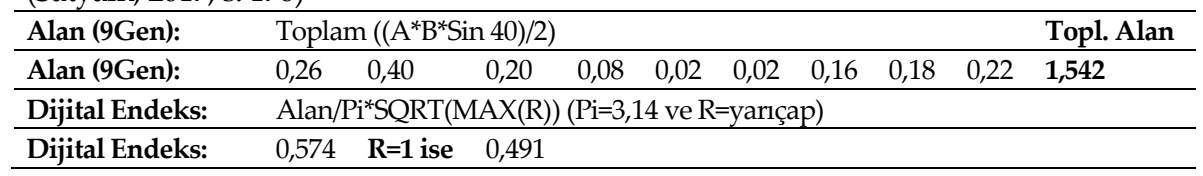


KDE'nin hesaplanmasında $\mathrm{R}$ (yarıçap) Oran sütunundaki en büyük değer olan 1,37 alınmıştır. İkinci hesaplamada ise $\mathrm{R}=1$ alınmıştır. Ancak Tablo6'daki sıralama ilk hesaplamaya göre verilmiştir. Tablo-3'deki her bir KBF'nin oranlarına bağlı olarak oluşturulan Zonguldak Merkez ilçe AK "Kent Dijitalleşme Haritası" Şekil-2'deki gibi oluşmuştur.

Tablo-5'den görüleceği gibi Merkez ilçe "Teknoloji Altyapısı" değerinin $(0,90)$ olması bu değerin Türkiye ortalamasının altında ve "İnsan Sermayesi" değerinin $(1,37)$ ise Türkiye ortalamasının üstünde olduğunu göstermektedir. Sonuçta Zonguldak ilçelerinin 88 adet göstergeye bakılarak Tablo-4'deki formüllerle hesaplanan KBF Oran sonuçları Tablo-5'de ve Kent Dijitalleşme Haritaları Şekil-3’de toplu olarak verilmiştir.

Tablo 5. Zonguldak İlçelerinin Dijital Dönüşüm Kritik Başarı Faktör Oranları

\begin{tabular}{lllllllll}
\hline KBF'ler & $\begin{array}{l}\text { Mer- } \\
\text { kez }\end{array}$ & $\begin{array}{l}\text { Kdz. } \\
\text { Ereğli }\end{array}$ & Alaplı & Kozlu & Kilimli & $\begin{array}{l}\text { Çay- } \\
\text { cuma }\end{array}$ & Devrek & Gökçebey \\
\hline Teknoloji Altyapısı & 0,90 & 0,85 & 1,07 & 0,79 & 0,85 & 0,71 & 0,70 & 0,63 \\
\hline Teknoloji Kabulü & 0,78 & 0,89 & 0,78 & 0,78 & 0,78 & 0,78 & 0,78 & 0,78 \\
\hline İnsan Sermayesi & 1,37 & 0,85 & 0,89 & 0,87 & 0,91 & 0,82 & 0,84 & 0,84 \\
\hline $\begin{array}{l}\text { İnsan İhtiyaçlarının } \\
\text { Karşılanması }\end{array}$ & 0,40 & 0,70 & 0,38 & 0,37 & 0,40 & 0,69 & 1,08 & 0,49 \\
\hline $\begin{array}{l}\text { Belediye } \\
\text { Yönetişimi }\end{array}$ & 0,53 & 0,46 & 0,10 & 0,10 & 0,11 & 0,36 & 0,52 & 0,11 \\
\hline $\begin{array}{l}\text { Akıllı Kent } \\
\text { Uygulamaları }\end{array}$ & 0,09 & 0,09 & 0,09 & 0,09 & 0,09 & 0,27 & 0,18 & 0,09 \\
\hline İş Yapma Kolaylığ1 & 0,59 & 0,58 & 0,54 & 0,58 & 0,54 & 0,58 & 0,54 & 0,50 \\
\hline Yenilik Ortamı & 0,72 & 0,33 & 0,20 & 0,23 & 0,21 & 0,44 & 0,35 & 1,09 \\
\hline Dijital Pazar & 0,67 & 0,67 & 0,62 & 0,62 & 0,62 & 0,67 & 0,67 & 0,62 \\
\hline Ortalama Oran & $\mathbf{0 , 6 7}$ & $\mathbf{0 , 6 0}$ & $\mathbf{0 , 5 2}$ & $\mathbf{0 , 4 9}$ & $\mathbf{0 , 5 0}$ & $\mathbf{0 , 5 9}$ & $\mathbf{0 , 6 3}$ & $\mathbf{0 , 5 7}$ \\
\hline Alan Değeri & $\mathbf{1 , 5 4}$ & $\mathbf{1 , 3 1}$ & $\mathbf{1 , 0 6}$ & $\mathbf{0 , 9 2}$ & $\mathbf{0 , 9 7}$ & $\mathbf{1 , 2 3}$ & $\mathbf{1 , 4 0}$ & $\mathbf{1 , 2 2}$ \\
\hline Dijital Endeks & $\mathbf{0 , 5 7}$ & $\mathbf{0 , 3 9}$ & $\mathbf{0 , 3 5}$ & $\mathbf{0 , 2 7}$ & $\mathbf{0 , 2 9}$ & $\mathbf{0 , 3 6}$ & $\mathbf{0 , 4 6}$ & $\mathbf{0 , 4 1}$ \\
\hline
\end{tabular}

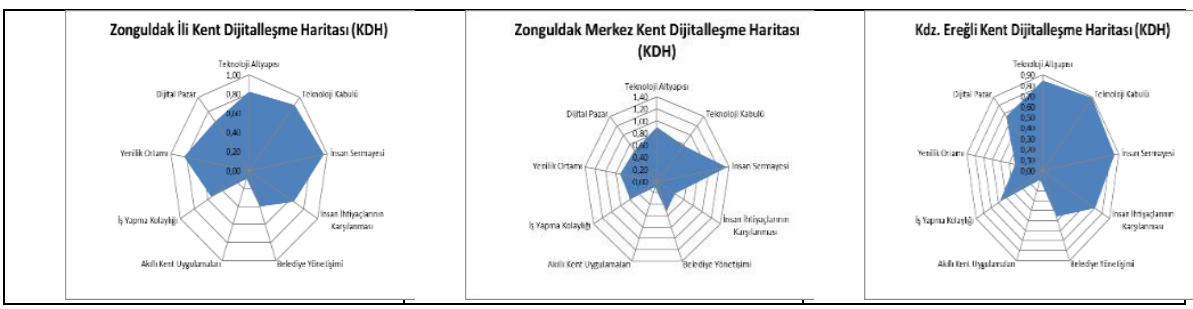




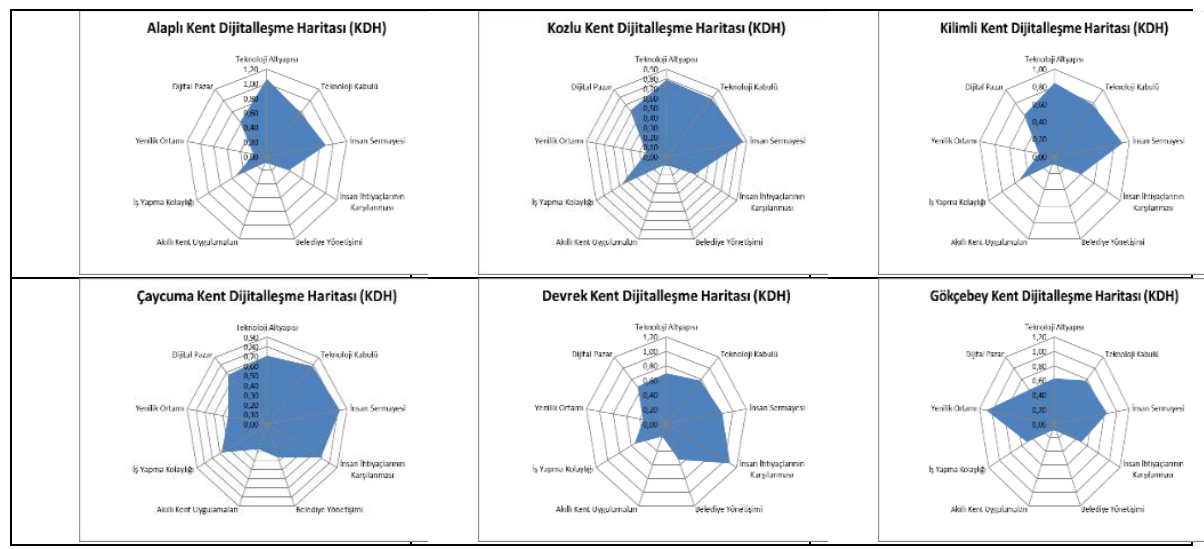

Şekil-3: Zonguldak İli ve İlçelerinin Kent Dijitalleşme Haritaları (KDH)

Hesaplanan Kent Dijitalleşme Endeks değerlerine göre ilçelerin sıralanması ise Tablo-6'daki gibi oluşmuştur.

Tablo 6. Zonguldak İlçeleri Kent Dijitalleşme Endeks Sıralaması

\begin{tabular}{lllll}
\hline İlçe & Nüfus & Belediye Nüfusu & $\begin{array}{l}\text { Dijitalleşme } \\
\text { Endeksi }\end{array}$ & $\begin{array}{l}\text { R=1 se } \\
\text { Endeks }\end{array}$ \\
\hline Zonguldak Merkez & 125.339 & 105.529 & 0,574 & 0,491 \\
\hline Devrek & 57.540 & 26.497 & 0,464 & 0,445 \\
\hline Gökçebey & 21.655 & 8.204 & 0,406 & 0,389 \\
\hline Kdz. Ereğli & 175.605 & 117.456 & 0,393 & 0,416 \\
\hline Çaycuma & 91.569 & 27.190 & 0,355 & 0,391 \\
\hline Alaplı & 44.286 & 19.301 & 0,348 & 0,337 \\
\hline Kilimli & 35.323 & 20.639 & 0,294 & 0,308 \\
\hline Kozlu & 48.381 & 40.853 & 0,273 & 0,293 \\
\hline
\end{tabular}

Zonguldak ilindeki bu araştırma bulgularına bakıldığında, KDE değerlerine göre Zonguldak merkez ilçesinin önde olduğu görülmektedir. Bunun en önemli sebebi kentteki üniversite öğrenci ve öğretim elemanı sayılarının Türkiye ortalamasının 2,5 katı olması, belediye Bilgi İşlem bütçesinin yüksekliği ve Bilgi İşlem bölümünün uygulamakta olduğu projeler olduğu söylenebilir. Devrek ilçesinin yüksek bir KDE'ye sahip olması ise TSO'ya kayıtlı şirket sayılarının nüfusuna göre yüksek olmasına, 3 adet tescillenmiş coğrafi işaretinin bulunmasına ve belediye Bilgi işlem bölümünün başarılı uygulamalarına bağlanabilir. Araştırmadaki en önemli sonuç Zonguldak ilinin en küçük ilçesi olan Gökçebey'in 3. sırada olmasıdır. Bunu sağlayanın da ilçe sınırları içerisinde önemli oranda bir Ar-Ge bütçesine sahip olan yenilikçi (inovatif) bir 
firma olduğu görülmektedir. Ulusal Creavit markasına sahip olan bu firmanın 15 adet tescillenmiş markası ve Türkiye ortalamasının çok üzerinde bir Ar-Ge bütçesinin olması kentin KDE değerini yukarıya çıkarmaktadır. Tüm ilçelerin KDH'larına bakıldığında en optimum dijitalleşmenin Çaycuma ilçesinde olduğu söylenebilir. Çünkü $\mathrm{KDH}^{\prime}$ daki KBF'lerin değerleri dengeli bir şekilde dağıldığı görülmektedir. Kentlerin Dijitalleşme stratejilerinden birisinin de dengeli KBF değerlerine ulaşmak olduğu da unutulmamalıdır.

Diğer yandan en yüksek KBF oranlarına (Tablo-5'deki kırmızı değerler) bakıldığında şu sonuçlar elde edilmiştir: İnsan Sermayesi, Belediye Yönetişimi ve İş Yapma Kolaylığı faktörlerinde en iyi Oran Zonguldak merkez ilçeye aittir. Teknoloji Kabulünde Kdz. Ereğli, İnsan İhtiyaçlarının Karşılanmasında Devrek, Yenilik Ortamında Gökçebey, Teknoloji Altyapısında Alaplı ve Akıllı Kent Uygulamalarında ise Çaycuma ilçesinin en yüksek değerlere sahip olduğu görülmektedir. Dijital Pazar gösterge verileri çoğunlukla Zonguldak ortalamasından geldiği için dört ilçe yaklaşık 0,67 değerini almıştır. Bu durum bu KBF değeri için gerçek verilere ulaşılamadığını göstermektedir.

İl bazında tüm Kent Dijitalleşme Haritalarına (Şekil-3) bakıldığında Zonguldak kentlerinin Teknoloji Altyapısı ve İnsan Sermayesi KBF'leri bakımından yüksek olduğu, Yenilik Ortamı, İş Yapma Kolaylığı, Belediye Yönetişimi ve AK Uygulamalarında ise düşük olduğu söylenebilir. Her bir kentin KDH ve KDE'sinin farklı olması her bir kentin farklı yönetimsel kararlara ihtiyaç duyduğunu ve her kentin ihtiyaçlarının belirlenmesinde göstergelerin ayrıntılı olarak analiz edilmesi gerektiğini göstermektedir.

\section{Sonuçlar}

Kentler Dünya'da yaşanan teknolojik ve sosyal değişimleri önleyemeyeceğine göre kendilerini bu değişimlere ayak uyduracak şekilde ayarlamalarını sağlayacak kent yöneticileri ve paydaşlarına sahip olmalıdır. Bunun için Kentsel yaşamda dijitalleşmeyi destekleyecek, kentlerin Akıllı Kent haline gelmesini sağlayacak ve Kent ekonomisini, rekabetçiliğini, sürdürülebilir hizmetleri ve ekosistemini anlayıp yönetecek dijitalleşmiş paydaşların (insanların) yetiştirilebileceği bir Eğitim-Öğretim 4.0 sistemi kentte hayata geçirilmelidir. Bu sayede kent yöneticileri ve paydaşlarının dijital okuryazarlığı sağlanabilir. Bu araştırmada ortaya konan $\mathrm{KDE}$ ve $\mathrm{KDH}^{\prime}$ lardan yararlanabilmek için dijital okuryazarlık özellikle kent yöneticiler için gerekli olan bir melekedir. Araştırma sonuçları kent yöneticilerinin dijital okuryazarlığına katkı sağlayabilir. 
Araştırmada kullanılan 88 adet göstergenin 12 tanesinin internetle ilgili olması İnternetin kent dijitalleşmesindeki önemini ortaya koymaktadır. Bu açıdan araştırma sonuçları kent yöneticilerinin her eve internet bağlantısı ve dijitalleşme stratejisinin bir kent için ne kadar önemli olduğunu kavramalarını sağlayabilir.

$\mathrm{Bu}$ araştırmada, kent yönetimi, kent rekabetçiliği, sürdürülebilirliği ve kaynaklarının etkin ve verimli kullanımının sağlanmasına yardımcı olacak yeni araçların (KDE ve KDH) ortaya çıktığı söylenebilir. Bu yüzden araştırma sonuçları Kent altyapı ve diğer belediye hizmetlerinin kontrolü için ilgili kent yönetimlerinde bir farkındalık yaratabilir. Ayrıca araştırma sonunda ortaya çıkarılan KDE ve KDH ve diğer BIT araçları yardımıyla kent kaynaklarının verimli ve etkin kullanımı için kent yöneticileri tarafından ilgili kararların alınmasına yardım edebilir.

Günümüz Dünya'sında nüfus ve veri artışına bağlı olarak insanların birçok teknolojik, sosyal, siyasal ve ekolojik sorunlarla uğraşmak zorunda olduğu aşikârdır. Daha önce belirtildiği gibi bu sorunları çözebilmek için paydaşlar arasında daha fazla işbirliği yapılmalıdır. Bu sorunların çözümünde kullanilabilecek araçlardan ikisi de KDH ve KDE olabilir.

$\mathrm{Bu}$ araştırmada kentlerin dijitalleşme seviyelerinin veya dijital dönüşüme (AK) hazırlık seviyelerinin ölçülmesi sağlanmaya çalışılmıştır. Kentin dijitalleşme seviyesini ölçen KDE kentin dijitalleşme sıralamasını ve diğer kentlerle karşılaştırılmasını sağladığından Kentin dijital altyapısı ve belediye hizmetlerinin optimize edilmesi için kullanılabilir. Kent Dijitalleşme Haritaları ise kentin hangi alanlarda yetersiz ve dijital dönüşümün neresinde olduğunu kolayca görselleştirerek kent yöneticilerinin dijitalleşme konusunda nerelerde eksikleri olduğunu anlamalarına yardım edebilir.

Diğer yandan kaynakların zamanla azaldığı düşünüldüğünde hâlihazırda var olan kent kaynaklarının etkin ve verimli bir şekilde kullanılmasının öncelikle gerekli olduğu görülmektedir. Halk kent yönetimlerinin bugün ve gelecekte sahip olacakları kaynakları, bugünün ve geleceğin ihtiyaçlarına göre etkili ve verimli bir şekilde kullanmasını beklemektedir ve demokratikleşme sürdügü sürece de bu durumun devam edeceği açıktır. Bunun için kullanılacak en önemli yöntemlerden birisi ülkenin, işletmelerin, öğretim sisteminin yanında kentlerin de dijitalleşmesini sağlamak olduğu söylenebilir. $\mathrm{Bu}$ açıdan bu araştırma sonunda belirlenen KDE ve KDH araçları Bilişim ve İletişim Teknolojilerinin kentlerde ve yönetiminde kullanımının yayginlaşmasına yardım edebilir. Ayrıca araştırma sonuçlarına bağlı olarak konunun 
önemi ve ivediliği konusunda ortaya çıkacak enformasyon kentlerin dijitalleşmesi için gerekli BITT araçlarının üretimi için Türk şirket ve yatırımcılarına motivasyon sağlayarak bu alanda yatırımların artmasına yardım edebilir.

Dijital teknolojilerin hızl gelişimi ve yaygınlaşması ve kentsel yaşamı etkilemeye başlaması bilim dünyasında ve yayıncılıkta ilgi çekmesini sağlamaktadır. Bu yüzden araştırma kentlerde BİT’lerin kullanımı, Kentlerin Dijital Dönüşümü ve Akıllı Kentler ile ilgili yeni araştırmalara referans olabilir.

Kentlerin sürdürülebilir bir ekonomik, sosyal ve fiziksel gelişim için yeni Endüstri 4.0 ve diğer Bilişim Teknolojileri yardımıyla yeniden AK olarak yapılandırılması gerekmektedir. Bu yapılandırma kentsel iç faktörlerin Dünya' da yaşanan dış faktörlerdeki değişimlere uydurulmasıyla gerçekleştirilmelidir. Bu yeniden yapılandırmada kullanılacak önemli araçlardan birisinin de Akıllı Kent uygulamalarının faydalarını ortaya koyabilecek KDE ve KDH'lar olabileceği söylenebilir.

Kentlerin detaylı dijital dönüşümünün incelenmesi sırasında KBF'lerin ağırlık değerlerinin bulunması da istenebilir. Bu ağırlık değerlerinin bir şehirden diğerine değişebileceği unutulmamalıdır. İstanbul, Teknoloji Altyapısına daha düşük, Belediye Yönetişimine daha yüksek ağırlık verirken, Zonguldak yönetimi ise tam tersini yapabilir. Bu ağırlıklı değerlere (W1, W2...) göre KDE'lerin bulunmasında Analitik Hiyerarşi Süreci (AHP) kullanılabilir. AHP ile uzmanlar veya kent yönetimlerinin her bir faktörün göreceli ağırlığını tanımlamaları sağlanarak daha detaylı ve kentte özel KDE/KDH'lar bulunabilir.

Ayrıca bu araştırmanın Türkiye'deki tüm iller bazında KDE'lerin çıkarılarak tüm kentlerin dijitalleşme sıralamasının çıkarılması önemli bir araştırma konusu olabilir. Dahası bu araştırma sonuçlarının uluslararası verilerle karşılaştırılması ülke şehirlerinin küresel açıdan değerlendirilmesini gösterebilir. 


\section{Extended Abstract}

\section{Ranking the Towns of Zonguldak Province According to the Urban Digitization Indices and Visualizing the Digitization Levels with Urban Digitalization Maps}

\author{
Mustafa Coruh \\ ORCID: 0000-0002-7114-0372
}

\author{
Halil İbrahim Cebeci \\ ORCID: 0000-0001-5058-7741
}

The integration of new mobile and digital technologies into city assets becomes important in the productive and effective implementation of urban services. One of the most important events of today seems to be the digitalization of cities which creates Smart Cities (SC). Smart City can be defined as "cities where data and information flow digitally, and physical and virtual assets are in communication in a digital environment". For this reason, the digital transformation of the cities and the "Urban Digitalization Index (UDI)" related to this transformation are becoming an important issue. Many indices in the world have been developed and continue to be developed in order to enable cities to be compared with each other depending on the level of being SC or digitalization. On the other hand, SC applications such as reading of water, natural gas and electricity meters with mobile technologies and invoicing them automatically, monitoring of weather, parking slots, garbage cans, roads and traffic situation by means of related Internet of Things (IoT) sensors and informing relevant stakeholders for helping to facilitate urban life as well as productive and effective use of urban resources. Besides, Smart City implementations have also started to offer important opportunities in ensuring city security, finding addresses, providing fluidity in traffic, saving energy and efficiency in using city resources, and activating digital municipal services (e-Municipality). Therefore, "Measuring the level of digitalization of cities has been identified as one of the most important problems (duties) of cities (managers)" and a solution was sought in this research. 
In this study the dimensions, Critical Success Factors (CSF) and indicators that affect digitalization of cities have been compiled by means of literature review and field interviews. With the help of an arranged Excel table, the indicators data affecting the digital transformation of eight towns in Zonguldak province were collected and the "Urban Digitalization Index" (UDI) of the towns was calculated and "Urban Digitalization Maps" (UDM) were used to visualize the digitalization status of each town. It is seen that the digitalization level of each town is different depending on the total values of the indicators listed in the prepared table. Collecting and analyzing the relevant indicator values from the municipalities, Chamber of Commerce and Industry (TSO), Türk Telekom, Police Department, SSI, TOBB, TIM, BTK, MEB, YÖK and national statistical institutions (TUIK) to measure each CSF with city data for measuring the level of digitalization and visualizing the effects of CSFs by UDM increases the importance of this study. It is also determining the dimensions, Critical Success Factors and indicators that enable the digitalization and transformation of the cities strengthens the importance of this research.

For the efficient and productive use of resources in cities, all data and information created, used and analyzed in the city should be digitized. So, there is a need for digitized data and information about city services, assets and resources. It is impossible to collect, store, analyze and distribute non-digitized data and information at the desired speed and to distribute them to decisionmakers or make them public usage. Considering that population growth and urbanization will continue and existing resources will decrease, it is seen that it is necessary to use the existing urban resources effectively and productively. Only the digitalization can be ensured to increase the productivity of the local workforce and local company innovations and to support the public entrepreneurship in the cities which are the competitive advantages of the cities. Therefore, "Measuring the level of Digitalization or Digital Transformation level of cities" reveals the importance of this research.

By determining the CSFs that affect the digitization of the cities and determining the indicators that make up these factors, the level of digitalization of the cities or the level of preparation for being SC can be determined. The aim of this research is to measure the UDI values of the towns in the province of Zonguldak by determining and analyzing the CSFs that affect the digitalization of the cities. In this research, answers to the following questions were sought in order to achieve this mentioned goal: 
- What are the dimensions, CSFs and indicators that define the digitalization of the cities?

- How to measure CSF values and find a digitization index value for cities?

- How can the cities be ranked by Urban Digitalization Index (UDI)?

- How can CSF values be visualized for city managers?

- What are the benefits of UDI and City Digitalization Maps (CDM) to city administrations and stakeholders?

There are many Target Audiences of the Research such as City and Municipality administrators, NGOs, public and local companies, companies providing infrastructure services, companies that offer SC applications, local and central public institutions.

In this study, the Urban Digitization Index and Digitalization Map of the cities were prepared by using the calculation method of (Satyam, 2017). In this calculation, a ratio was found by dividing the value of each indicator by the Total indicator value of the relevant CSF in order to calculate each CSF value. The final Urban Digitalization Index (UDI) value was calculated by calculating the rectangular areas (Figure-1) formed by these ratio values and dividing this value to total value of the defined circle.

The research was carried out on 8 town municipalities of Zonguldak province and the research was completed on equal weighted indicator data values. When looking at all the Urban Digitalization Maps for Zonguldak towns, it can be said that Zonguldak towns are high in terms of Technology Infrastructure and Human Capital CSFs and low in Innovation Environment, Ease of Doing Business, Municipal Governance and SC Applications. The fact that each town's UDM and UDIs are different which indicates that each town needs different administrative decisions and the indicators should be analyzed in detail in determining the needs of each town.

It should be remembered that in this research, instead of finding solutions that can enable the digitalization of cities, a common calculation method is tried to be developed that can rank the cities according to the calculated UDI values.

\section{Kaynakça/References}

Ahvenniemi, H., Huovila, A., Pinto-Seppä, I., ve Airaksinen, M. (2017). What are the differences between sustainable and smart cities? Cities, 60, 234-245.

ATGM. (2018). Toplam AR-GE merkez sayısı. Ekim 23, 2019 tarihinde https://atgm.sanayi.gov.tr/Handlers/DokumanGetHandler.ashx?dokumanId=0f2b 8c0e-d0cc-46a6-b7d0-4a4ed4b6ec0a adresinden alındı 
Banger, G. (2017). Endüstri 4.0 ekstra. Ankara: Darlion Yayınları.

Banger, G. (2018). Endüstri 4.0 ve akıllı işletme (2. Baskı). Ankara: Darlion Yayınları.

Berger, R. (2019). The smart city breakaway. How a small group of leading digital cities is outpacing the rest. Ağustos 20, 2019 tarihinde https://www.rolandberger.com/publications/publication_pdf/roland_berger_smart _city_breakaway_1.pdf adresinden alındı

Borja, J., ve Castells, M. (1997). Local and Global: Management of Cities in the Information Age. United Nations Centre for Human Settlements (Habitat). UNCHS. UK: Earthscan Publications Ltd.

Bourdieu, P. (1984). Distinction: A Social critique of the judgement of taste. London \& New York: Routledge.

BSI. (2015). Smart cities overview-guide. BSI:PD 8100.

BTGM. (2019). Teknoloji geliştirme (Teknokent) bölgeleri. Ekim 22, 2019 tarihinde https://btgm.sanayi.gov.tr/Handlers/DokumanGetHandler.ashx?dokumanId=4d9b 6b9a-839b-446e-af35-aafe40b65946 adresinden alındı

BTK. (2018). Genişbant internet kullanıcı sayıları. Ekim 19, 2019 tarihinde https:/www.btk.gov.tr/uploads/pages/yillik-il-istatistikleri/elektronik-haberlesmesektorune-iliskin-il-bazinda-yillik-istatistik-bulteni-2019-v2.pdf adresinden alınd1

CBS Müdürlüğü. (2019). Akıllı şehirler beyaz bülteni. Aralık 24, 2019 tarihinde https://webdosya.csb.gov.tr/db/cbs/akillisehirler/ adresinden alındı

CI. (2019). Coğrafi işaretler. Kasım 11, 2019 tarihinde https://www.ci.gov.tr/anasayfa adresinden alınd 1

Cisco. (2018). Cisco Australian digital readiness index 2018: Digital dividend or digital divide? Ağustos 20, 2019 tarihinde https://www.cisco.com/c/dam/m/en_au/digitalreadiness/pdfs/digital-readiness-report.pdf adresinden alındı

Cohen, B. (2015). The smartest cities In the World 2015: Methodology. Ağustos 27, 2019 tarihinde https://www.fastcompany.com/3038818/the-smartest-cities-in-the-world2015-methodology adresinden alınd1

Coruh, M. (2009). The factors involved in utilizing e-Municipality and municipal wireless network (MWN) technologies for effective, efficient and productive use of city resources in municipal governments in the information age. Ph.D Thesis, International School of Management, Paris.

Coşkun, R., Altunışık, R., ve Yıldırım, E. (2017). Sosyal bilimlerde araştırma yöntemleri SPSS uygulamah (9. Baskl). Sakarya: Sakarya Kitabevi, Ağustos 2017.

Çoruh, M. (2010). Kent kaynaklarının etkin ve verimli kullanımında kablosuz belediye internet ağlarının (KBIA) etkileri. Akademik Bilişim 2010 Konferansı (10-12 Şubat 2010). Muğla: Muğla Üniversitesi.

Çoruh, M. (2016). Bilişim kentleri çă̆̆. Ankara: Post ve Post Yayıncılık, Ocak 2016.

Çoruh, M. (2021). Kentlerin dijital dönüşümü için kritik başarı faktörlerinin belirlenmesi ve Kent dijitalleşme endeksi ile kent dijitalleşme haritasının çıkarılması. Sakarya Üniversitesi İşletme Enstitüsü YBS Bölümü, Savunulmamış Doktora Tezi. 
EBSO. (2017). Sanayi 4.0 uyum sağlamayan kaybedecek (Düzeltilmiş 2. Baskl). Ege Bölgesi Sanayi Odasi. Ekim 15, $2017 \quad$ tarihinde http://www.ebso.org.tr/ebsomedia/documents/sanayi-40--gozden-gecirilmis-ikincibaski_95869497.pdf adresinden alındı

EDCi. (2016). European Digital City Index methodology report. Ağustos 20, 2019 tarihinde https://digitalcityindex.eu/uploads/2016\%20EDCi\%20Construction\%20Methodolo gy\%20FINAL.pdf adresinden alınd1

Eğitimsen. (2018). Türkiye'de ortalama okul süresi (yıl). Ekim 8, 2019 tarihinde http://egitimsen.org.tr/2018-2019-egitim-ogretim-yilinda-egitimin-durumu-raporu/ adresinden alındı

Endustri40. (2018a). Dördüncü endüstri devrimi sanayinin dijitalleşmesi. Haziran 10, 2018 tarihinde https://www.endustri40.com/dorduncu-endustri-devrimi-sanayinindijitallesmesi adresinden alınd

Gökmen, L. (2016, July 1). Konutta proje ligi. Ekonomist: http://www.ekonomist.com.tr/kapak-konusu/konutta-proje-ligi.html adresinden alınd 1

Türkiye'de ortalama yaşam beklenti süresi (yıl). (2019). Habertürk Ekim 9, 2019 tarihinde https://www.haberturk.com/turkiye-de-beklenen-yasam-suresi-78-3-yil-2524926 adresinden alınd 1

Herzberg, C. (2017). Akıllı şehirler dijital ülkeler. (N. Özata, Çev.) İstanbul: Infoloji Smart Solution, Optimist Yayın Grubu, Kasım 2017.

Huang, Z., Gao, J., ve Liu, R. (2019). Discussion on the key success factors of developing smart eco-city based on Analytic Hierarchy Process. Ekoloji, 28(10), 1651-1657. Ağustos 20, 2019 tarihinde http://www.ekolojidergisi.com/download/discussionon-the-key-success-factors-of-developing-smart-eco-city-based-on-analytichierarchy-5791.pdf adresinden alındı

IBM. (2016). How smart is your city? Helping cities measure progress. Ağustos 30, 2019 tarihinde https://www.ibm.com/downloads/cas/KLEYQE6Z adresinden alınd1

IMD. (2017). Smart City Index summary of criteria. Ağustos 22, 2019 tarihinde https://www.imd.org/smart-city-observatory/smart-city-index/ adresinden alınd 1

Invest. (2018). Türkiye'deki toplam yabancl yatırımcl sayısı. Ekim 25, 2019 tarihinde http://v1.invest.gov.tr/tr-TR/turkey/factsandfigures/Pages/TRSnapshot.aspx adresinden alınd 1

İren, D. (2018). Dördüncü endüstri deorimi sanayinin dijitalleşmesi. Haziran 10, 2018 tarihinde http://www.endustri40.com/dorduncu-endustri-devrimi-sanayinindijitallesmesi/ adresinden alındı

Kamrysi, K., Gotzamani, K., Andronikidis, A., ve Georgiou, A. C. (2014). Capturing and prioritizing students' requirements for course design by embedding Fuzzy-AHP and Linear Programming in QFD. Eur J Oper Res: 10831094, 237(3).

Kesikoğlu, F. (2019). Göstergelerle Zonguldak ekonomisi raporu. Zonguldak TSO. 
KOBITEK. (2014). Toplam firma sayılar. Ekim 22, 2019 tarihinde https://kobitek.com/turkiyede-kac-sirket-var adresinden alındı

Murray, J. (1900). Murray's hand-book constantinople Brusa, and the Throad. London: John Murray.

Nic.tr. (2018). Toplam TR web alan adlart. Ekim 20, 2019 tarihinde https://www.nic.tr/index.php?USRACTN=STATISTICS adresinden alınd 1

Nick, G., \& Pongrácz, F. (2016). How To measure industry 4.0 readiness of cities. Scientific Proceedings I International Scientific Conference "Industry 4.0" 2016 ISSN 13103946. Ağustos 21, 2019 tarihinde http://industry4.eu/winter/sbornik/2016/2/16.HOW\%20TO\%20MEASURE\%20INDUSTRY\%204.0 \%20READINESS\%20OF\%20CITIES.pdf adresinden alındı

Roitman, S. (2010). Gated communities: definitions, causes and consequences. Urban Design and Planning, 163(1), 31-38.

Rojek, C. (2000). Indexing, dragging and the social construction of tourist sights. C. R. Urry içinde, Touring cultures. Transformation of travel and theory (s. 52-74). New York: Routledge.

Satyam, A. (2017). The smart city transformations (e-Book). New Delhi: Bloomsbury Publishing India Pvt. Ltd., January 2017.

SBB. (2019). Türkiye bütçesi. Ekim 22, 2019 tarihinde http://www.sbb.gov.tr/2019butcesine-genel-bakis/ adresinden alındı

SCRanking. (2007). Smart cities - Ranking of European medium-sized cities. Ağustos 20, 2019 tarihinde http://www.smart-cities.eu/download/smart_cities_final_report.pdf adresinden alındı

SGB. (2018). Yetişkin BT/Bilgisayar/Programcılık kursu veren kurum sayısı+Halk Eğitim Merkezi. Ekim 23, 2019 https://sgb.meb.gov.tr/www/icerik_goruntule.php?KNO=361 adresinden alınd 1

TiM. (2019). Türkiye'nin eylül 2019 ihracat tutarı. Ekim 23, 2019 tarihinde https://www.tim.org.tr/tr/ihracat-rakamlari.html adresinden alındı

TOBB. (2018). Toplam kapanan şirket (Şirket, Kop, Kişi) istatistikleri. Ekim 22, 2019 tarihinde https://www.tobb.org.tr/BilgiErisimMudurlugu/Sayfalar/KurulanKapananSirketist atistikleri.php adresinden alınd 1

TT. (2018). Türk Telekom ile güçlü Belediyeler, mutlu vatandaşlar. Türk Telekom akıllı şehirler kataloğu. İstanbul.

TUBISAD. (2019a). Sosyal medya ve e-Ticaret kullanıct istatistikleri. Ekim 19, 2019 tarihinde Http://www.tubisad.org.tr/tr/images/pdf/dd-tusiad-eticaret-raporu-2019.pdf adresinden alınd 1

TUiK. (2018). Türkiye nüfus verileri. Ekim 8, 2019 tarihinde http://www.tuik.gov.tr/ adresinden alındı

TUIK. (2018a). AR-Ge harcama tutarı Ekim 23, 2019 tarihinde http://tuik.gov.tr/PreTabloArama.do adresinden alındı

TUіK. (2019). Bilgisayar kullanıcı sayılan (masaüstü, dizüstü, tablet, netbook). Ekim 19, 2019 tarihinde http://www.tuik.gov.tr/PreTablo.do?alt_id=1028 adresinden alındı 
TUіK. (2019a). Şirketlerin bilgisayar ve web kullanım oranları. Ekim 22, 2019 tarihinde http://tuik.gov.tr/PreHaberBultenleri.do?id=30573 adresinden alındı

Webdosya. (2019). Zonguldak belediye yüzölçümleri. Ekim 30, 2019 tarihinde https://webdosya.csb.gov.tr/db/mpgm/editordosya/file/CDP_25000/Zonguldak/PL ANACIKLAMARAPORU_06072017.pdf adresinden alındı

Wien. (2019). Smart City Wien: Framework strategy. Ağustos 30, 2019 tarihinde Https://smartcity.wien.gv.at/site/files/2016/12/SC_LF_Kern_ENG_2016_WEB_Einz el.pdf adresinden alınd 1

YÖK. (2019). Türkiye'de üniversite, öğretim görevlisi ve önlisans-lisans-master-doktora öğrenci sayısı. Ekim 8, 2019 tarihinde https://istatistik.yok.gov.tr/ adresinden alınd

Zikmund, W. G. (2000). Business research methods (6th addition). Texas, USA: Dryden Press. Nisan 22, 2009 tarihinde http://www.un.org/esa/population adresinden alınd 1 